\title{
OBSTACLES AND STRATEGY OF MUNICIPAL ISLAMIC BONDS ISSUANCE AS AN ALTERNATIVE OF MUNICIPAL FUNDING
}

\author{
Asa Jasmine Harimurti ${ }^{1 *}$ and Achmad Zaky \\ ${ }^{1,2}$ Universitas Brawijaya, Malang, Indonesia
}

\begin{abstract}
The objective of this thesis is to identify obstacles and strategies for municipal Islamic bond issuance as an alternative in regional financing using the Analytical Networking Process (ANP). The analysis found that the most dominant obstacle in the aforementioned issue is the local government aspect. In the aspect of the central government, the obstacle is the unavailability of studies concerning the instrument of municipal Islamic bonds. In the aspect of the local government, the obstacle is the low understanding of the government about the means of municipal Islamic bonds. In the aspect of the regional house of representative, the obstacle is the behaviour of representatives, in which they complicate bureaucracy in the issuance of municipal Islamic bonds. The most dominant solution for the obstacles and strategy in the issuance of municipal Islamic bonds is a fundamental solution. The dominant strategy for a fundamental solution is the socialization of education about municipal Islamic bonds and a promotion pattern in collaboration with Indonesia's financial service authority.
\end{abstract}

Keywords: municipal Islamic bonds, obstacle, strategy

\section{INTRODUCTION}

Decentralization is a fundamental in government management marked with the presence of a division of authority and the availability of an ideal public space for interpereting authority to lower level government units or known as municipal governments (Hadi, 2005). A clear and strict seperation in the matter of central government finance with municipal governments is a form of fiscal decentralization (Isdijoso and Wibowo, 2002). In the implementation of fiscal decentralization, the central government provides funding support with the authority to collect tax and retribution in the area which is known as locally generated revenue. Other than that the central government provides funding support through transfers or what is often known as municipal fund transfers in the form of Balancing Funds which are Revenue Sharing Funds, Public Allocation Funds, and Specific Allocation Funds.

The income source which municipal governments obtain are assessed as very limited, because the funding source obtaind from the central government is much absorbed into routine spending (Kaluge and Okta, 2011). With an all limited financial condition it is confirmed that municipal governments have difficulties for implementing several development, infrastructure and renovation projects of public facilities because of the limited funds owned. This condition indicates the need for municipal governments to implement innovation soon for covering the funding gap size by searching for municipal funding alternatives. The implementation of Act Number 33 Year 2004 about

${ }^{1}$ Corresponding author. Email address : jasmineharimurti@gmail.com 
Financial Balnce between the Central Government and Municipal Governments and Act number 32 year 2004 about Municipal Governments, provides Municipal Governments the opportunity for collecting funds as a funding alternative from other municipal income sources, one of which is by the issuance of securities.

The presence of a syariah based financial system (syariah finance) is growing rapidly , and adopted by several countries in the world. The syariah finance growth which is massive is marked with the issuance of several syariah based financial instruments in several countries one of which is the islamic bond. According to the National Syariah Council fatwa no 41/DSN-MUI/III year 2004, islamic bonds are one of the long term securities based on the syariah principle issued by emittance to islamic bond holders that requires issuers to pay income to islamic bond holders in the form of revenue sharing/margin/fee and paying back the islamic bond fund in the due date. According to Act No 19 year 2008 about National Syariah Securities, other than being used as a source of national funding, the issuance of the islamic bond instrument is also used as infrastructure development project funding such as: developing toll roads, bridges, dams, airports, and power plants.

Research related with the opportunity of using municipal islamic bonds in Indonesia is still limited to the analysis of the ability of a municipal in issuing municipal islamic bonds and the benefit of issuing municipal islamic bonds. When studied in depth, the primary obstacle in the municipal islamic bond issuance is that there is not yet a municipal that is able to collect funds by issuing securities. In another point, the opportunity of municipal islamic bond issuance is very large, considering the law in Indonesia supports issuing municipal securities. Because of that, there is a need for searching obstacles that underlies the problem of municipal islamic bond issuance in Indonesia, and there is a need for formulating strategy and recommendations which are able to solve the present obstacles.

\section{RESEARCH METHOD}

This research uses the Analytical Networking Process (ANP) approach in identifying obstacle factors and issuing strategies of municipal islamic bonds as an alternative of municipal funding in Indonesia. The ANP approach is able to absorb a value or view which scholars, practitioners, and regulators represent. The ANP method selection in this research is implemented based on the fact that municipal islamic bond issuance, especially municipal bonds, have not yet been realized by Municipal Governments, even though there is already a regulation that allows the issuance of municipal bonds. Other than that, specific regulations of municipal bonds have not yet been regulated in Indonesia, other than comparing the benefit of municipal islamic bonds as a municipal funding alternative which has much potential to support municipal development. So, in line with the ANP method, this research needs expert respondents in the fields of municipal funding and syariah finance which are able to provide views relevant with the obstacles and strategy of islamic bond issuance.

Research of obstacles and strategy of municipal islamic bond issuance as a municipal funding alternative in Indonesia is implemented in accordance with the ANP research phases. Beginning with a literature review in the form of journals, books, and regulations related with islamic bonds and municipal funding, and implementing an in depth interview with an expert in the municipal 
funding field. The result from the literature review and the interview is validated by experts, practitioners and regulators. The result from filling the questionnaire is processed and analyzed, so it produces a conclusion about obstacles and strategy as a municipal funding alternative.

The data source used is a primary data obtained from the result of in depth interviews and questionnaire fillings by respondents. According to Narimawati (2008), primary data is data from the real source or the first and is not present in the compiled form. Respondents of this research are the experts, practitioners, and regulators by examining respondents' competence to obstacles an strategy of municipal islamic bond issuance as an alternative of municipal funding in Indonesia. The number of respondents in this research consist of 7 (seven) persons which consist of experts, practitioners, and regulators, because in the ANP analysis the sample/respondent number is not used as a validity benchmark. The requirement for a respondent to be valid in ANP is that the respondent is a competent person in the field (Ascarya, 2005). Meanwhile, data gathering methods used in this research are interviews and questionnaires.

Table 1 Experts Involved in the Research

\begin{tabular}{|c|c|c|c|}
\hline No & Name & Position and Institution & Party \\
\hline 1. & Rijanta Tri Wahjono & $\begin{array}{c}\text { Head of Syariah Law Documents Section, } \\
\text { Directorate General of Finance and Risk } \\
\text { Management }\end{array}$ & Regulator \\
\hline 2. & Sugeng Wahyu Hendarto & $\begin{array}{c}\text { Head of the Development Sub Directorate, } \\
\text { National Planning Agency }\end{array}$ & Regulator \\
\hline 3. & Nur Sigit Warsidi & $\begin{array}{c}\text { Director of the Syariah Capital Market, Financial } \\
\text { Services Authority }\end{array}$ & Regulator \\
\hline 4. & Noven Suprayogi & $\begin{array}{c}\text { Head of the Syariah Economy Study Program, } \\
\text { Faculty of Economics and Business Airlangga } \\
\text { University }\end{array}$ & $\begin{array}{l}\text { Expert and } \\
\text { Practitioner }\end{array}$ \\
\hline 5. & Sigit Kurnianto & $\begin{array}{c}\text { Executive Director of East Java Indonesia } \\
\text { Accountant Bond }\end{array}$ & $\begin{array}{l}\text { Expert and } \\
\text { Practitioner }\end{array}$ \\
\hline 6. & San Rudiyanto & Internal Supervising Unit, Brawijaya University & $\begin{array}{l}\text { Expert and } \\
\text { Practitioner }\end{array}$ \\
\hline 7. & Pemerintah Daerah Jawa Barat & Staff of the economics and development division & $\begin{array}{l}\text { Municipal } \\
\text { Government }\end{array}$ \\
\hline
\end{tabular}

\section{Source: writer processed}

The implemented ANP research phases consist of 9 (nine) phases among others: 1) Problem identification, implemented by reading articles about the absence of municipals which are able to issue islamic regional bonds as a municipal funding alternative for obtaining topics and the research gap; 2) A literature review and in depth interview is implemented for obtaining independent variables from literature and interview results; 3) Expert validation is implemented for reducing independent variables which are relevant with the present problem; 4) The questionnaire arranging and the ANP scheme is created based on reducted variables by experts and the scheme is created with a software super decision; 5) An expert survey is implemented by filling questionnaires and studies related with the strategy with respondents; 6) The data analysis is a process of searching and arranging obtained data systematically by using the software super decision; 7) Data interpretation is implemented by combining all ANP scheme results which are processed in the data analysis phase by using microsoft excel; 8) The analysis result is the result of the average priority count of all respondents which then will be created into a variable ranking list; 9) The conclusion is the final phase of all the ANP research phases. 


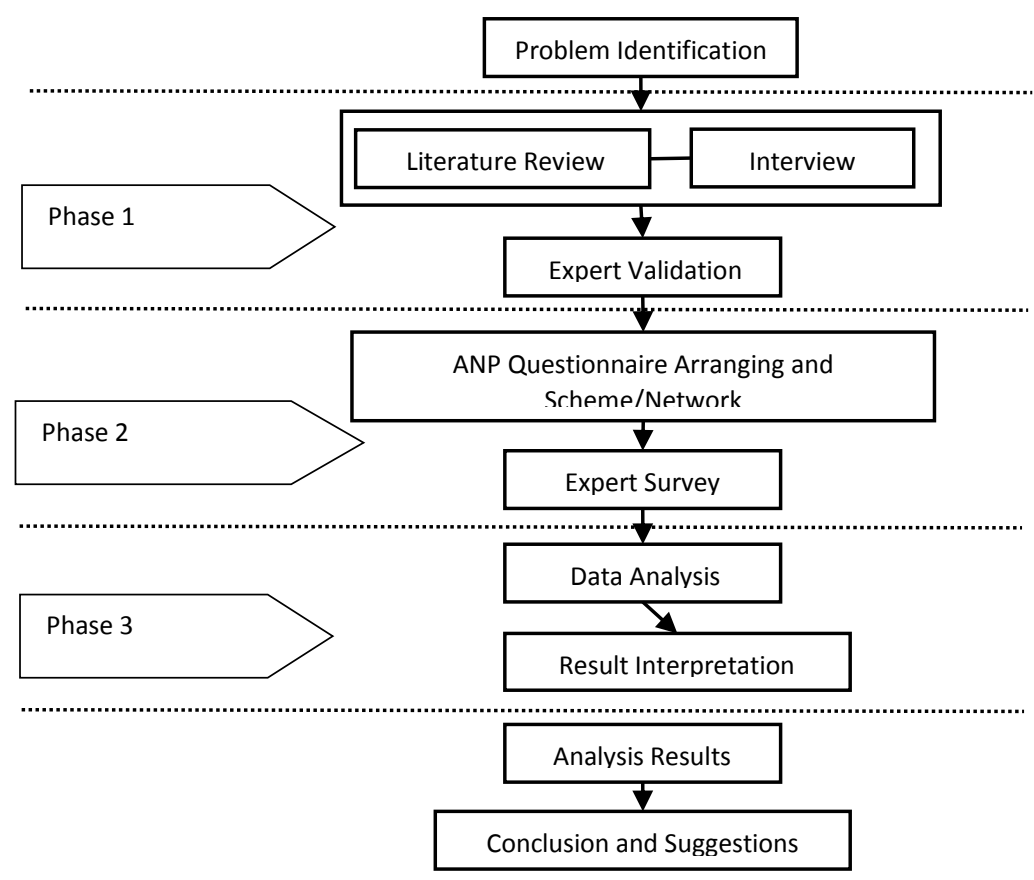

Figure 1 ANP Research Phases

\section{DISCUSSION}

\section{Obstacles and Strategy of Municipal Islamic Bond Issuance as a Municipal Funding Alternative}

Based on literature review and interview results with competent sources in the fields of municipal islamic bond issuance and municipal funding, so the expert validation is then implemented in reducing variables which are assessed to be related with the obstacle of the issuance of municipal islamic bonds as a municipal funding alternative. The variable reduction table of the expert validation results is able to be seen in table 1 and the expert validation recapitulation result is able to be seen in table 2. Meanwhile the municipal bond issuance strategy variable becomes a reference in implementing an in depth study with respondents for arranging the mapping action plan matrix.

Table 2 Reduction Variables of Expert Validation Results

1. Obstacle Variables of the Central Government Aspect

\section{Obstacles}

Central Government Aspect

K1.1 The absence of incentives in igniting municipal bond issuance as a funding alternative (Shidiq, 2017)

K1.2 The complicated bureaucracy of municipal islamic bond issuance (Ardhian, 2017)

K1.3 The absence of a review about the municipal islamic bond instrument (Shidiq, 2017)

2. Obstacle Variables of the Municipal Government Aspect

Obstacles

Municipal Government Aspect

K2.1 The low understanding of municipal governments to the municipal islamic bond instrument (interview result of Rudiyanto, 2017) 
K2.2 The tendency to avoid municipal islamic bond issuance risk and selecting another form of funding (Solehudin, 2017)

K2.3 The low commitment of municipal islamic bond planning (Pontjowinoto, 2016)

3. Obstacle Variables of the Municipal People's Representative Council

\begin{tabular}{ll}
\hline \multicolumn{1}{c}{ Obstacles } \\
\hline Municipal People's Representative Council Aspect \\
\hline K3.1 & $\begin{array}{l}\text { Complicates the bureaucracy of the municipal bond issuance instrument } \\
\text { (interview result of Rudiyanto, 2017) } \\
\text { Less pro-active with the planning implemented by the Municipal Government } \\
\text { (interview result of Rudiyanto, 2017) }\end{array}$ \\
\hline
\end{tabular}

4. Obstacle Variables of the Investor Aspect

Obstacles

\begin{tabular}{ll}
\hline Investor Aspect \\
\hline K4.1 & $\begin{array}{l}\text { A conservative attitude with an orientation for profit from investment results } \\
\text { (interview result of Rudiyanto, 2017) }\end{array}$ \\
K4.2 & $\begin{array}{l}\text { An attitude of lesser trust of Municipal Government credibility (interview result } \\
\text { of Rudiyanto, 2017) }\end{array}$ \\
\hline
\end{tabular}

5. Obstacle Variables of the Capital Market Aspect

\section{Obstacles}

\section{Capital Market Aspect}

K5.1 The absence of equal knowledge of market players related with syariah based investment (interview result of Rudiyanto, 2017)

K5.2 The limited number of syriah based market players (interview result of Rudiyanto, 2017)

6. Roadmap Strategy Variable

\begin{tabular}{ll}
\hline Roadmap Strategy & Strategy \\
\hline S3.1 & $\begin{array}{l}\text { Arranging a grand design of the education pattern and promoting municipal } \\
\text { islamic bonds in an interesting way collaborating with the Financial Services } \\
\text { Authority }\end{array}$ \\
S3.2 & $\begin{array}{l}\text { Implementing a structured and sustainable evaluation with investors and the } \\
\text { Central Government related with municipal islamic bonds }\end{array}$ \\
S3.3 & $\begin{array}{l}\text { Improving the domestic investor base and opening the market for foreign } \\
\text { investors }\end{array}$ \\
\hline & Technical Strategy Variable \\
\hline Technical Strategy & \multicolumn{1}{c}{ Strategy } \\
\hline S2.1 & $\begin{array}{l}\text { Completing the issuance regulations of municipal islamic bond issuance } \\
\text { S2.2 }\end{array}$ \\
S2.3 & Socialization of the municipal islamic bond issuance regulations \\
\hline
\end{tabular}


8. Fundamental Strategy Variable

\begin{tabular}{ll}
\hline \multicolumn{1}{c}{ Strategy } \\
\hline Fundamental Strategy \\
\hline S1.1 & $\begin{array}{l}\text { Education and training related with municipal islamic bonds } \\
\text { S1.2 }\end{array}$ \\
$\begin{array}{l}\text { Optimizing the application of New Public Management for improving Municipa } \\
\text { Government performance }\end{array}$ \\
S1.3 & $\begin{array}{l}\text { The preparation of supporting professions and institutions of municipal islamic } \\
\text { bond issuance }\end{array}$ \\
\hline
\end{tabular}
Source: writer processed

Based on the data processing result related with the obstacles and strategy of municipal islamic bond issuance as an alternative of municipal funding, the following results are obtained:

Table 3 Priority Rank Data Processing Results

\begin{tabular}{|c|c|c|}
\hline Aspect & Average Rank & Rank \\
\hline Central Government & 0.295198333 & 3 \\
\hline Municipal Government & 0.352806667 & 1 \\
\hline Municipal People's Representative Council & 0.351563333 & 2 \\
\hline Central Government & Average Rank & Rank \\
\hline Incentive & 0.329666667 & 2 \\
\hline Complicated bureaucracy & 0.32875 & 3 \\
\hline review & 0.341171667 & 1 \\
\hline Municipal Government & Average Rank & Rank \\
\hline Municipal Government Understanding & 0.336263333 & 1 \\
\hline Risk avoidance & 0.329273333 & 3 \\
\hline Low commitment & 0.33282 & 2 \\
\hline Municipal People's Representative Council & Average Rank & Rank \\
\hline Complicates bureaucracy & 0.339575 & 1 \\
\hline Less pro-active & 0.32995 & 3 \\
\hline Conservative attitude & 0.331806667 & 2 \\
\hline Solution & Average Rank & Rank \\
\hline Fundamental Solution & 0.378063333 & 1 \\
\hline Technical Solution & 0.333073333 & 2 \\
\hline Roadmap Solution & 0.286123333 & 3 \\
\hline Technical Solution & Average Rank & Rank \\
\hline Education and training & 0.376788333 & 1 \\
\hline Optimizing Student Numbers & 0.35821 & 2 \\
\hline Profession and institutions & 0.265001667 & 3 \\
\hline Fundamental Solution & Average Rank & Rank \\
\hline Completing regulations & 0.339735714 & 2 \\
\hline Socialization of regulations & 0.365322857 & 1 \\
\hline Fixing complicated regulations & 0.297317143 & 3 \\
\hline Roadmap Solution & Average Rank & Rank \\
\hline Arranging the grand design & 0.3341 & 1 \\
\hline Structured and sustainable evaluation & 0.31187 & 2 \\
\hline Improving the domestic and foreign investor base & 0.29937 & 3 \\
\hline
\end{tabular}




\section{OBSTACLES AND STRATEGY OF MUNICIPAL ISLAMIC BONDS ISSUANCE AS \\ AN ALTERNATIVE OF MUNICIPAL FUNDING}

\section{Municipal Islamic Bond Issuance Action Plan Matrix}

Table 4 Action Plan Mapping Matrix of Municipal Islamic Bond Issuance as a

Funding Alternative

\begin{tabular}{|c|c|c|c|c|c|}
\hline No & PHASE & ASPECT & SOLUTION & STRATEGY & RECCOMENDATION \\
\hline 1 & \multicolumn{5}{|c|}{ Planning of Municipal Islamic Bond Issuance } \\
\hline $\mathrm{a}$ & $\begin{array}{l}\text { The planning of } \\
\text { municipal } \\
\text { islamic bond } \\
\text { issuance has to } \\
\text { be followed by a } \\
\text { project proposal } \\
\text { and a study } \\
\text { document } \\
\text { preperation of } \\
\text { the project } \\
\text { worthiness } \\
\text { study. }\end{array}$ & $\begin{array}{l}\text { Municipal } \\
\text { Government } \\
\text { Aspect, where } \\
\text { planning is } \\
\text { implemented by } \\
\text { project initiators, } \\
\text { the proposed } \\
\text { project is only a } \\
\text { project that is } \\
\text { allocated in the } \\
\text { Municipal } \\
\text { Income Spending } \\
\text { Budget, can be in } \\
\text { the form of a } \\
\text { project which will } \\
\text { be or in the } \\
\text { process of being } \\
\text { built }\end{array}$ & Fundamental & $\begin{array}{l}\text { Education and } \\
\text { Training related } \\
\text { with municipal } \\
\text { islamic bonds }\end{array}$ & $\begin{array}{l}\text { The education and } \\
\text { training related with } \\
\text { municipal islamic bonds } \\
\text { is implemented so } \\
\text { Municipal Governments } \\
\text { and the Municipal } \\
\text { People's Representative } \\
\text { Council understands the } \\
\text { project which can be } \\
\text { funded through } \\
\text { municipal islamic bond } \\
\text { issuance }\end{array}$ \\
\hline $\mathrm{b}$ & $\begin{array}{l}\text { Assessment of } \\
\text { project } \\
\text { worthiness and } \\
\text { approval }\end{array}$ & $\begin{array}{l}\text { Central } \\
\text { Government and } \\
\text { Municipal } \\
\text { People's } \\
\text { Representative } \\
\text { Council Aspect, } \\
\text { where the } \\
\text { Readiness } \\
\text { Criteria and MUI } \\
\text { standard have } \\
\text { released } \\
\text { regulations of the } \\
\text { project criteria in } \\
\text { corresponding } \\
\text { with syariah } \\
\text { principles. Other } \\
\text { than that,the } \\
\text { municipal islamic } \\
\text { bond issuance } \\
\text { needs the } \\
\text { Municipal } \\
\text { People's } \\
\text { Representative } \\
\text { Council's } \\
\text { approval in } \\
\text { municipal islamic } \\
\text { bond issuance. }\end{array}$ & Fundamental & $\begin{array}{l}\text { Education and } \\
\text { Training related } \\
\text { with municipal } \\
\text { islamic bonds }\end{array}$ & $\begin{array}{l}\text { The readiness criteria } \\
\text { and the MUI standard } \\
\text { regulations need to be } \\
\text { socialized to Municipal } \\
\text { Governments and the } \\
\text { Municipal People's } \\
\text { Representative Council } \\
\text { so it is able to be a } \\
\text { project assessment in } \\
\text { determining the project } \\
\text { priority list. }\end{array}$ \\
\hline 2 & Municipal Islamic & Bond Issuance Budg & eting & & \\
\hline $\mathrm{a}$ & $\begin{array}{l}\text { Municipal } \\
\text { Income }\end{array}$ & $\begin{array}{l}\text { Municipal } \\
\text { Government }\end{array}$ & Technical & $\begin{array}{l}\text { Regulation } \\
\text { Socialization }\end{array}$ & $\begin{array}{l}\text { The allocation of the } \\
\text { Municipal Income }\end{array}$ \\
\hline
\end{tabular}


AFEBI Islamic Finance and Economic Review (AIFER)

Vol.03 No.01, June 2018

\begin{tabular}{|c|c|c|c|c|c|}
\hline No & PHASE & ASPECT & SOLUTION & STRATEGY & RECCOMENDATION \\
\hline & $\begin{array}{l}\text { Spending } \\
\text { Budget } \\
\text { Allocation }\end{array}$ & $\begin{array}{l}\text { Aspect, the } \\
\text { advantage of the } \\
\text { municipal islamic } \\
\text { bond as a } \\
\text { municipal } \\
\text { funding } \\
\text { alternative is not } \\
\text { yet felt compared } \\
\text { with other sources } \\
\text { of funding. }\end{array}$ & & $\begin{array}{l}\text { related with } \\
\text { municipal } \\
\text { islamic bonds }\end{array}$ & $\begin{array}{l}\text { Spending Budget in the } \\
\text { form of budget items of } \\
\text { project capiital spending } \\
\text { which guarantee fund } \\
\text { liquidation of project } \\
\text { funding, yet the } \\
\text { budgeting item for } \\
\text { spending of } \\
\text { compensation payment } \\
\text { and the nominal value of } \\
\text { municipal islamic bond } \\
\text { issuance is also needed. }\end{array}$ \\
\hline $\mathrm{b}$ & $\begin{array}{l}\text { Budgeting } \\
\text { Implementation } \\
\text { Document } \\
\text { Arranging }\end{array}$ & $\begin{array}{l}\text { Municipal } \\
\text { Government } \\
\text { Aspect, The fund } \\
\text { liquidation } \\
\text { mechanism is not } \\
\text { yet clear in the } \\
\text { project } \\
\text { implementation that } \\
\text { is funded through } \\
\text { municipal islamic } \\
\text { bonds }\end{array}$ & Technical & $\begin{array}{l}\text { Regulation } \\
\text { Socialization } \\
\text { Related with } \\
\text { Municipal } \\
\text { Islamic Bonds }\end{array}$ & $\begin{array}{l}\text { The fund liquidation } \\
\text { mechanism is adapted with } \\
\text { the determined regulations } \\
\text { specifically for municipal } \\
\text { islamic bonds }\end{array}$ \\
\hline 3 & \multicolumn{2}{|c|}{ Municipal Islamic Bond Issuance } & & & \\
\hline $\mathrm{a}$ & $\begin{array}{c}\text { Planning of } \\
\text { issuance and sales } \\
\text { of municipal } \\
\text { islamic bonds }\end{array}$ & $\begin{array}{c}\text { Municipal } \\
\text { Government Aspect }\end{array}$ & Technical & $\begin{array}{l}\text { Completing the } \\
\text { regulations of } \\
\text { municipal } \\
\text { islamic bond } \\
\text { issuance }\end{array}$ & $\begin{array}{l}\text { The planning and sales } \\
\text { process of municipal } \\
\text { islamic bonds needs } \\
\text { regulations that are clear } \\
\text { and detailed so the } \\
\text { implementation can be in } \\
\text { line with the regulations } \\
\text { determined by the Central } \\
\text { Government }\end{array}$ \\
\hline $\mathrm{b}$ & $\begin{array}{l}\text { Issuance } \\
\text { implementation } \\
\text { and sales of } \\
\text { municipal islamic } \\
\text { bonds }\end{array}$ & $\begin{array}{l}\text { Municipal } \\
\text { Government } \\
\text { Aspect, the } \\
\text { implementation of } \\
\text { the issuance and } \\
\text { sales need to be } \\
\text { supervised }\end{array}$ & Roadmap & $\begin{array}{l}\text { Arranging the } \\
\text { grand design } \\
\text { pattern and } \\
\text { promoting } \\
\text { municipal } \\
\text { islamic bonds } \\
\text { attractively } \\
\text { collaborating } \\
\text { with the } \\
\text { Financial Service } \\
\text { Authority }\end{array}$ & $\begin{array}{l}\text { The regulation of issuance } \\
\text { and sales need to be } \\
\text { followed by education and } \\
\text { promotion to society which } \\
\text { will be municipal bond } \\
\text { investors }\end{array}$ \\
\hline $\mathrm{c}$ & $\begin{array}{l}\text { Administration } \\
\text { issuance and } \\
\text { municipal islamic } \\
\text { bond sales }\end{array}$ & $\begin{array}{l}\text { Municipal } \\
\text { Government } \\
\text { Aspect, financial } \\
\text { obstaceles are able } \\
\text { to be revealed in } \\
\text { the administration } \\
\text { of municipal } \\
\text { islamic bond sales }\end{array}$ & Roadmap & $\begin{array}{l}\text { Implementing a } \\
\text { structured } \\
\text { evaluation } \\
\text { program with } \\
\text { investors and the } \\
\text { Central } \\
\text { Government } \\
\text { related with } \\
\text { municipal } \\
\text { islamic bonds }\end{array}$ & $\begin{array}{l}\text { The progress and } \\
\text { administration results need } \\
\text { to be informed to investors } \\
\text { as holders of municipal } \\
\text { islamic bonds and the } \\
\text { Central Government as the } \\
\text { regulator by holding a } \\
\text { structured evaluation } \\
\text { program }\end{array}$ \\
\hline $\mathrm{d}$ & $\begin{array}{l}\text { Portfolio and risk } \\
\text { management }\end{array}$ & $\begin{array}{l}\text { Municipal } \\
\text { Government } \\
\text { Aspect, risks can be }\end{array}$ & Roadmap & $\begin{array}{l}\text { Implementing a } \\
\text { structured } \\
\text { evaluation }\end{array}$ & $\begin{array}{l}\text { The finding of risks and } \\
\text { portfolio management need } \\
\text { to be informed to investors }\end{array}$ \\
\hline
\end{tabular}




\begin{tabular}{|c|c|c|c|c|c|}
\hline No & PHASE & ASPECT & SOLUTION & STRATEGY & RECCOMENDATION \\
\hline & & $\begin{array}{l}\text { identified some } \\
\text { years after the } \\
\text { municipal islamic } \\
\text { bonds are published }\end{array}$ & & $\begin{array}{l}\text { program with } \\
\text { investors and the } \\
\text { Central } \\
\text { Government } \\
\text { related with } \\
\text { municipal } \\
\text { islamic bonds }\end{array}$ & $\begin{array}{l}\text { as the municipal islamic } \\
\text { bond holders and the } \\
\text { Central Government as the } \\
\text { regulator by holding an } \\
\text { evaluation program }\end{array}$ \\
\hline
\end{tabular}

The exposure in the action plan mappig matrix clearly shows that there is an influential relation between aspect processing results, obstacles, solutions and the priority strategy or dominant with every phase of municipal islamic bond issuance as an alternative to municipal funding. It clearly shows than the Municipal Government aspect appears as many as 7 (seven) times in all the subphases of municipal islamic bond issuance, in line with the selection of Municipal Governments as the most dominant aspect compared with other aspects. It is able to be concluded that Municipal Governments are parties which are not yet ready and not yet commited in issuing municipal islamic bonds as an alternative of municipal funding, even though the Central Government already provided incentives in the form of policies which tell that Municipal Governments are provided opportunities in issuing securities.

The strategy in the fundamental solution is also filled by the education and training strategy related with municipal islamic bonds which is also the most dominant strategy compared with other strategies. The intended education and training is a continuation of the Central Government's policy and the policy related with municipal islamic bonds has to be followed specifically and education and training need to be provided to apertures in the funding division in Municipal Governments. Other than that, the strategy in the technical solution is also dominated by the strategy of regulation socialization related with municipal islamic bonds and is also the most dominant strategy compared with other strategies. It is able to be concluded that, after there are specific regulations related with municipal islamic bonds, The Central Government needs to implement the present policy socialization in the frame of educating Municipal Governments and the Municipal People's Representative Council about the importance of the funding factor through securities, one of which is the municipal islamic bond.

\section{CONCLUSION}

Based on research analysis results to obstacles and strategy of municipal islamic bond issuance as a municipal funding alternative, the following conclusion is obtained:

1. Research results show that the obstacles of municipal islamic bond issuance as an alternative to municipal funding consist of 3 (three) aspects which are the Central Government aspect, the Municipal Government aspect, and the Municipal People's Representative Council aspect. As a whole, the dominant obstacle or which becomes the priority obstacle and the strategy of islamic bond issuance is the Municipal Government aspect. As for the most dominant obstacle in each aspect are: 1) In the Central Government aspect the most dominant is the absence of a review about the municipal islamic bond instrument; 2) In the Municipal Government aspect the most dominant is the low understanding of Municipal Governments to the 
municipal islamic bond instrument; 3) in the Municipal People's Representative Council aspect the most dominant is the complicated bureaucracy of municipal islamic bond issuance. The most dominant solution in the obstacles and strategy of municipal islamic bond issuance is a fundamental solution. While the most dominant strategy in each solution is: 1) A fundamental solution, education and training related with municipal islamic bonds; 2) A technical solution, socialization of regulations of municipal islamic bond issuance; 3) A roadmap solution, arranging the grand design of the education pattern and promonting municipal islamic bons effectively collaborating with the Financial Services Authority.

2. The action plan matrix mapping shows that there is an influential relation between aspect processing results, obstacles, solutions and the priority strategy or dominant with each phase of municipal islamic bond issuace as a municipal funding alternative. The Municipal Government Aspect appears as many as 7 (seven) times in the whole sub-phase of municipal islamic bond issuance, the strategy in the fundamental solution is filled with the education and training strategy related with municipal islamic bonds, and the strategy in the technical solution is also dominated by the socialization strategy of regulations related with municipal islamic bonds, which are all the most dominant variables.

\section{References}

Ali, M. (2010). Metodologi dan Aplikasi Riset Pendidikan. Bandung: Pusataka Cendikia Utama

Ardhian, M. (2017). Penerbitan Surat Utang Daerah Terkendala Perizinan yang Rumit.https://katadata.co.id/berita/2017/09/11/penerbitan-surat-utangdaerah-terkendala-perizinan-yang-rumit. akses 25 September 2017

Ascarya. (2010). The Development of Islamic Financial System In Indonesia And The Way Forward. Journal of Bank Indonesia. Jakarta: Bank Indonesia.

Badan Pendidikan dan Pelatihan Keuangan. (2010). Desentralisasi Fiskal dan Pengelolaan APBD di Indonesia. Jakarta: LPKAP.

Bapepam. (2003). Panduan Investasi di Pasar Modal Indonesia. Jakarta: Bappepam.

Cahyadin., \& Indriana. (2005). Kemungkinan Penerapan Obligasi Daerah: Studi Kasus Pemerintah Daerah di Profinsi Jawa Timur. Surabaya: Ikatan Sarjana Ekonomi Indonesia.

Direktorat Jenderal Perimbangan Keuangan, Kementerian Keuangan. (2007). Panduan Penerbitan Obligasi Daerah. Jakarta: DJPK.

Direktorat Pembiayaan Syariah-Direktorat Jendral Pengelolaan Utang Departemen Keuangan-RI. (2008). Kajian Pembiayaan Proyek dengan Penerbitan SBSN Istishna-Ijarah. Jakarta: DJPU.

Direktorat Jendral Pengelolaan Utang-Kemenkeu. (2009). Perkembangan Utang Negara (Pinjaman Luar Negeri dan Surat Berharga Negara). Jakarta: DJPU. 
Direktorat Pembiayaan Syariah-Direktorat Jendral Pengelolaan Utang Departemen Keuangan-RI. (2010). Tanya Jawab Surat Berharga Syariah Negara (Sukuk Negara) Instrumen Keuangan Berbasis Syariah. Jakarta: DJPU.

Ester, A., \& Haryanto, J. T. (2007). Studi Analisis Dampak Desentralisasi Fiskal Terhadap Pelauanan Sektor Publik. Jurnal Ekonomi Indonesia

Fiona, L., Taufik, T., \& Ratnawati, V. (2016). Analisis Kapasitas Fiskal Dan Pengaruhnya terhadap Anggaran Belanja Modal Pada Pemerintah Daerah Di Sumatera. Jurnal Ekonomi Universitas Riau, 21(2).

Gunawan, I. (2013). Metode Penelitian Kualitatif : Teori dan Praktik. Jakarta: PT. Bumi Aksara.

Gusliana, R. M., \& Dahlifah. (2016). Perbandingan Kinerja Obligasi Syariah Versus Obligasi Konvesional Di Indonesia. Jurnal Ekonomi, 23(1).

Hadi, S. (2005). Pilkada Bima 2005: Era Baru Demokratisasi Lokal di Indonesai. NTB: Bina Swagiri-Fitra Tuban-Solud.

Hulwati. (2017). Investasi Sukuk: Perspektif ekonomi syariah. Jurnal Ekonomi dan Bisnis Islam, 2.

Husaini, U., \& Purnomo. (2008). Metodologi Penelitian Sosial. Jakarta: PT Bumi Aksara.

Jatmiko. (2012). Kendala dan Kelayakan Surat Berharga Syariah Negara sebagai Alternatif Pembiayaan Proyek Infrastruktur Bandar Udara Kertajati di Kabupaten Majalengka. Jakarta: Universitas Indonesia

Komalasari, et al. (2011). Asesmen Teknik Non Tes Perspektif BK Komprehensif. Jakarta: PT.Indeks

Kunarjo. (1996). Perencanaan dan Pengendalian Program Pembangunan. Jakarta: UI Press.

Lestari, Y. O., \& Pratomo, A. S. (2015). Potensi sukuk daerah dalam pembiayaan infrastruktur di kota malang. Malang: UIN Maulana Malik Ibrahim.

Mahmudi. (2010). Manajemen Kinerja Sektor Publik, Yogyakarta: UPP STIM YKPN.

Mardiasmo. (2002). Otonomi dan Manajemen Keuangan Daerah. Yogyakarta: Andi.

Maryani, M. (2016). Pasar Modal Syariah. Iqtisodiyah: Jurnal Ekonomi dan Bisnis Islam,1(1), 53-66.

Mutmainah, C. M. (2017). Analisis Potensi Penerbitan Sukuk Daerah dan Dampaknya Terhadap Kemandirian Keuangan Daerah Jawa Barat (studi pada Wilayah Kabupaten/Kota di Jawa Barat Tahun 2015). Yogyakarta: Universitas Muhammadiyah Yogyakarta

Nerimawati, U. (2008). Metodologi Penelitian Kualitatif dan Kuantitatif: Teori dan Aplikasi. Jakarta: Salemba Empat. 
Okta, D., \& Kaluge, D. (2011). Analisis Peluang Penerbitan Obligasi Daerah Sebagai Alternatif Pembiayaan Daerah. Journal of Indonesian Applied Economics, 5(2).

Peraturan Menteri Keuangan Nomor 120/PMK.08/2011 tentang Penggunaan Proyek Sebagai Dasar Penerimaan SBSN.

Peraturan Menteri Keuangan nomor 45/PMK.02/2006 tentang pedoman pelaksanaan dan mekanisme pemantauan defisit anggaran pendapatan dan belanja daerah dan pinjaman daerah

Peraturan Pemerintah Nomor 56 Tahun 2011 tentang Pembiayaan Proyek Melalui Penerbitan Surat Berharga Syariah Negara.

Peraturan Nomor IX.A 13 tahun 2009 tentang Penerbitan Efek Syariah

Peraturan Menteri Keuangan Nomor 37/PMK.07/2016 Tentang Peta Kapasitas Fiskal Daerah.

Peraturan Pemerintah nomor 54 tahun 2005 Tentang Pengelolaan Keuangan Daerah.

Peraturan Pemerintah Nomor IX.A 13 tahun 2009 tentang penerbitan efek syariah

Permadi, S. (2017). Perkembangan Sukuk Negara Untuk Pembangunan Infrastruktur.http://www.iaei-pusat.org/id/article/ekonomisyariah/perkembangan-sukuk-negara-untuk-pembangunan-infrastruktur. akses 28 September 2017

Pramono, I. M., Sigit., \& Aziz, S. (2008). Peran Obligasi Syariah dalam Pengembangan Infrastruktur. http://www.Konsultasi Muamalat, akses 25 September 2017

Purnamawati, I. (2013). Perbandingan Sukuk Dan Obligasi (Telaah Dari Perspektif Keuangan Dan Akuntansi).Jurnal Akuntansi Universitas Jember, 11(1).

Rizkiyanti, S. (2015). Islamic Financial Mendunia, Indonesia Merger Perbankan

Syariah.https://www.kompasiana.com/www.kompasiana.santi.com/islam ic-financial-mendunia-indonesia-merger-perbankansyariah_555461d5b67e611618ba54c3. akses 28 September 2017

Rizal, J. (2017). Jenis-jenis Sukuk Indonesia. https://www.kompasiana.com/julianarizal/sukuk-dan-jenis-jenis-sukukindonesia_591b25231cafbd1075971132. akses 28 September 2017

Saaty, T. L. (1994). Fundamentals of Decision Making and Priority Theory with the Analytic Hierarcky Process. USA: RWS Publication.

Saaty, T. L. (2001). Decision Making with Dependence and Feedback: The Analytical Network Process. USA: RWS Publication. 
Saaty, T. L., \& Vargas, L. G. (2006). Decision Making with the Analitic Network Process. Economic, Political, Social and Technological Applications with Benefits, Opportunities, Costs and Risk. USA: Springer.

Shodiq, M. (2012). Urgensi Sukuk bagi Pemerintah Daerah. https://saepudinonline.wordpress.com/2012/07/17/urgensi-sukuk-bagipemerintah-daerah/. akses 25 September 2017

Siskawati, E. (2010). Perkembangan Obligasi Syariah di Indonesia: Suatu Tinjauan. Jurnal Akuntansi \& Manajemen Vol 5 No 2. Padang: Politeknik Negeri Padang.

Sudaryanti, N., Mahfud., A. A., \& Wulandari, R. (2014). Analisis Determinan Peringkat Sukuk dan Peringkat Obligasi di Indonesia. Tazkia Islamic Finance and Business Review, 6(2). Bogor: Tazkia

Sugiyono. Metode Penelitian Kuantitatif, Kualitatif dan R\&D. Bandung: Alfabeta

Sutedi, A. (2009). Aspek Hukum Obligasi dan Sukuk. Jakarta: Sinar Grafika

Tim Pengembangan Instrumen Pembiyaan Syariah. (2008). Pembiayaan Proyek dengan Penerbitan SBSN Istishna-Ijarah. Studi Kasus: Pembiayaan Proyek Jembatan Suramadhu. Jakarta: Departemen Keuangan Republik Indonesia

Tim Penulis Dewan Syariah Nasional MUI. (2003). Himpunan Fatwa Dewan Syariah Nasional. Jakarta: PT Intermasa.

Tim Studi Investasi Syariah Pasar Modal Indonesia. (2004). Studi tentang Investasi Syariah di Pasar Modal Indonesia. Jakarta: Bappepam.

Undang-undang Nomor 19 tahun 2008 tentang Surat Berharga Syariah negara

Undang-undang Nomor 22 tahun 2011 tentang Anggaran Pendapatan dan Belanja Negara

Undang-Undang Nomor 25 tahun 1999 tentang Perimbangan Keuangan Pusat dan Daerah

Undang-undang Nomor 32 tahun 2004 tentang Pemerintah Daerah

Undang-udang Nomor 33 tahun 2004 tentang Perimbangan Keuangan antara Pemerintah Pusat dan Pemerintah Daerah

Wahid, N. A. (2010). Sukuk: Membedah Obligasi pada Perbankan Syariah. Yogyakarta: Ar-Ruzz Media.

Wahyuni, Y. S. (2011). Analisis komparasi imbal hasil dan risiko sukuk dengan menggunakan harga pasar dan harga wajar (studi kasus sukuk yang diterbitkan di Indonesaia periode 2009-2011). Jakarta: Universitas Indonesia.

Walidi. (2009). Peta Penawaran dan Permintaan atas Penerbitan Sukuk Daerah. Jakarta: Universitas Indonesia 
AFEBI Islamic Finance and Economic Review (AIFER)

Vol.03 No.01, June 2018

Wibowo, T., \& Isdijoso, B. (2002). Analisis Kebijakan Fiskal Pada era Otonomi Daerah (Studi Kasus: Sektor Pendidikan Di Kota Surakarta). Jakarta

Zakik, K., \& Widita. (2016). Analysis of Municipal Sukuk Issuance and Impact on Regional Financial Independence in East Java Province. Malang: Universitas Brawijaya. 